\title{
Evaluation of Perspectives of Healthcare Professionals and Others Towards Cancer: Survey Study
}

\author{
Sağlık Çalışanı Olan ve Sağlık Çalışanı Olmayanların Kansere Yaklaşımının \\ Değerlendirilmesi: Anket Çalışması
}

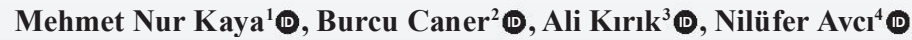 \\ Department Of Hematology, Mustafa Kemal University, Hatay, Turkey \\ Department Of Oncology, Balıkesir Atattürk City Hospital, Balıkesir, Turkey \\ Department Of Internal Medicine, Balıkesir University, Balıkesir, Turkey \\ Cite as: Kaya MN, Caner B, Kurlk A, Avc1 N. Evaluation of perspectives of healthcare professionals and others towards cancer: survey study. Kocaeli Med J 2021;10(2):63-68.
Department Of Oncology, Medicana Hospital, Bursa, Turkey
}

Abstract

INTRODUCTION: Cancer patients may experience various physical and psychological problems depending on the disease. It has been determined that as the general attitudes taken towards cancer have become negative in healthy individuals, attitudes taken towards the curability of cancer have also become negative. We aimed to evaluate the differences in the perspective of healthy individuals on cancer, and to compare healthcare professionals and non-healthcare professionals from this point of view. METHODS: The questionnaire was filled out face-to-face by two separate groups of people, one of which comprised healthcare professionals and the other comprised people that are not healthcare professionals. Both groups'approaches to cancer were evaluated by means of this questionnaire consisting of 11 questions, through which the demographic and professional characteristics of the participants were questioned first. RESULTS: A statistically significant difference $(p<0.01)$ was found between the two groups in terms of the answers given to the following five questions. No statistically significant difference was found between the two groups in terms of answers given to other questions.

DISCUSSION AND CONCLUSION: There was a significant difference between the two groups in terms of the answers given to certain questions included in the questionnaire. We think that the fact that healthcare professionals have more contact with cancer patients and especially that they can follow the diagnosis and treatment process of such patients more closely, compared to the group, which does not include any healthcare professionals, was effective in obtaining this result.

Keywords: health employee, cancer, questionnaire

Öz

GIIRIŞ ve AMAÇ: Kanser hastaları, hastalığa bağlı olarak çeşitli fiziksel ve psikolojik problemler yaşamaktadır. Sağlıklı bireylerde kansere karşı genel tutumların negatif hale gelmesiyle, kanserin iyileştirilebilirliğine yönelik tutumların da negatif olduğu tespit edilmiştir. Biz sağlıklı bireylerin kansere bakış açısındaki farklılıkların değerlendirilmesini, sağ lık çalışanları ve sağlık çalışanı olmayan bireylerin bu açıdan karşılaştırılmasını amaçladık.

YÖNTEM ve GEREÇLER: Anket, sağlık çalışanı olan ve sağlık çalışanı olmayan kişilerden oluşan iki ayrı grup arasında yüz yüze dolduruldu. Her iki grubun kansere yaklaşımları, ilk olarak katılımcıların demografik ve mesleki özelliklerinin sorgulandığı 11 sorudan oluşan bu anket aracılı̆̆ıly değerlendirildi. BULGULAR: Ankette beş soruya verilen cevaplar açısından iki grup arasında istatistiksel olarak anlamlı bir fark bulundu $(\mathrm{p}<0.01)$. Bu sorular, yakınında kanser teşhisi olan birinin olup olmadığı, kanser tarama programlarına katılım düzeyi, kanser teşhisinin hastayla paylaşılması, ötenazi hakkı ve kanser tanısını yakınlarıyla paylaşma kararı ile ilgiliydi. Diğer sorulara verilen cevaplar açısından iki grup arasında istatistiksel olarak anlamlı bir fark bulunmamıştır.

TARTIŞMA ve SONUÇ: Ankette yer alan sorulara verilen cevaplar açısından iki grup arasında anlamlı bir fark vardı. Sağlık çalışanlarının kanser hastalarıyla daha fazla teması olduğu ve özellikle bu hastaların teşhis ve tedavi sürecini, herhangi bir sağlık çalışanı olmayan gruba kıyasla daha yakından takip edebilmelerinin bu sonucu elde etmede etkili olduğunu düşünüyoruz.

Anahtar Kelimeler: sağlık çalışanı, kanser, anket
Geliş tarihi / Received:

14.10.2020

Kabul tarihi / Accepted:

17.06.2021

Sorumlu Yazar/Corresponding Author:

Mehmet Nur Kaya

Mustafa Kemal Üniversitesi Tip Fakültesi

Hastanesi 31000 Hatay - Türkiye mehmetnurkaya@yahoo.com ORCID: 0000-0003-4368-3078

B. Caner 0000-0003-1591-3323

A. Kırlk 0000-0002-7982-9262

N. Avcı 0000-0003-1094-5772

Anahtar Kelimeler: saglik çalşant, kanser, anket 


\section{INTRODUCTION}

Cancer ranks second among the causes of death in the world after cardiovascular diseases (1). According to the data provided by the World Health Organization, a total of 9.6 million people died from cancer in 2018, which means that cancer was the cause of death in one of every 6 deaths. Although cancer is among the preventable diseases, cancer screening is important in terms of preventing the disease and the complications that may arise after recovering from the disease. It should be aimed to make a diagnosis in the early stages when the treatment is still effective and much easier. Any healthcare service that targets the population at risk for cancer and which is carried out by means of the tests and examinations performed before the presentation of symptoms and clinical manifestations can be considered as cancer screening (2). In addition to being a serious and chronic disease, cancer is perceived as a disease that includes uncertainty, brings to mind death in pain and agony, and causes panic and anxiety. The physical burden of cancer can result in people that underwent cancer treatment to bear negative emotions towards the disease, and in their social isolation, and this makes it more difficult to cope with the disease when integrated with social attitudes. Such negative attitudes reduce the chances of survival of the patients, give rise to their social exclusion, cause isolation resulting in decreased social support, decrease emotional well-being, and lead to poor health outcomes (3). Cancer patients may experience various physical and psychological problems depending on the disease, which they may also experience during the treatment phase. Psychological problems generally include anxiety, depression, and compliance problems to cancer sequelae (4). It has been determined in a study conducted in healthy individuals that as the general attitudes taken towards cancer have become negative, attitudes taken towards the curability of cancer have also become negative (5). We have conducted this survey study in order to determine the differences between the approaches of healthcare professionals and others towards cancer.

\section{MATERIALS AND METHODS}

This survey study was conducted in two hospitals in 2019. The questionnaire was filled out face-to-face by two separate groups of people, one of which comprised healthcare professionals and the other comprised people that are not healthcare professionals. Both groups' approaches to cancer were evaluated by means of this questionnaire consisting of 11 questions, through which the demographic and professional characteristics of the participants were questioned first. The Faculty of Medicine Ethics Committee approved this study in (2019/70) accordance with the Helsinki Declaration. Written informed consent was obtained from each individual who participated in the study.

\section{Statistical analysis}

Mean, median and percentage were used for demographic characteristics. Chi-square tests were used as descriptive statistical methods for the purpose of statistical analysis. P $<0.05$ values were considered to be statistically significant. All statistical analyzes of this study were performed using the Statistical Program for Social Sciences (SPSS) version 23.0 software.

\section{RESULTS}

A total of 521 people participated in our study, consisting of healthcare professionals that include doctors, nurses, health officers, and medical secretaries, as well as others that are not healthcare professionals. $231(25 \%)$ of the participants were male and $390(75 \%)$ of them were female. 191 (36\%) of the participants were healthcare professionals, whereas the remaining $320(64 \%)$ were not. The average ages of the patients, healthcare professionals, and others were $42( \pm 16), 31( \pm 9)$, and $49( \pm 16)$, respectively. $147(77 \%)$ of the 191 healthcare professionals participated in the study had a university/ college level educational background, which means that the educational level in the group of healthcare professionals was mostly university/college level, whereas $152(46.1 \%)$ of the 320 people participated in the study had a primary school level educational background, which means that the educational level in the group of others that are not healthcare professionals was mostly primary school level (Table 1). 55 (28.8\%) of the healthcare professionals answered "yes" to the $2^{\text {nd }}$ question of this survey study, that is "Have you participated in cancer

Table 1. Distribution of certain sociodemographic and physical characteristics of patients $(n=521)$

Healthcare Other
Professional

\section{Certain}

$\begin{aligned} & \text { Sociodemographic } \\ & \text { Characteristics }\end{aligned}$
n

\section{Gender}

$\begin{array}{llrlr}\text { Male } & 77 & 40,3 & 154 & 46,7 \\ \text { Female } & 114 & 59,7 & 176 & 53,3 \\ \text { Age (years) } & \text { Mean } \pm \text { SD: } 31 \pm 9 & \text { Mean } \pm \text { SD: } 49 \pm 16 \\ & \text { Median: } 29 & \text { Median: } 49 \\ & \text { Youngest: } 19 & \text { Youngest: } 18 \\ & \text { Oldest: } 68 & \text { Oldest: } 90\end{array}$

\section{Educational Level}

\begin{tabular}{lllll} 
Literate & 1 & 0,5 & 30 & 9,1 \\
Primary Education & 2 & 1 & 152 & 46,1 \\
Secondary & 41 & 21,5 & 76 & 23 \\
$\begin{array}{l}\text { Education } \\
\text { University/ }\end{array}$ & 147 & 77 & 72 & 21,8 \\
Academy & & & & \\
\hline
\end{tabular}

*Column Percent 
screening programs?", whereas only 61 (18.5\%) of others that are not healthcare professionals answered "yes" to the same question, and thus a statistically significant difference $(\mathrm{p}<0.01)$ was found between the two groups in terms of their answers given to the said $2^{\text {nd }}$ question. $110(\% 57,6)$ of the healthcare professionals answered "yes" to the $4^{\text {th }}$ question of this survey study, that is "Do you have someone in your family or among your close ones diagnosed with cancer?", whereas only 141 $(\% 42,7)$ of others that are not healthcare professionals answered "yes" to the same question, and thus a statistically significant difference $(p<0.01)$ was found between the two groups in terms of their answers given to the said $4^{\text {th }}$ question. $115(\% 60,2)$ of the healthcare professionals responded to the $6^{\text {th }}$ question of this survey study, that is "How would you like someone among your close ones to find about him/her having been diagnosed with cancer?" by stating that they would like their close one, who has been diagnosed with cancer, to be told directly about their diagnosis, whereas $189(\% 57,3)$ of others that are not healthcare professionals responded to the same question by stating that they would like their close one, who has been diagnosed with cancer, not to be told about their diagnosis and that another close one is to be told about it instead, and thus a statistically significant difference $(p<0.01)$ was found between the two groups in terms of their answers given to the said $6^{\text {th }}$ question. $114(\% 59,7)$ of the healthcare professionals answered "no" to the $7^{\text {th }}$ question of this survey study, that is "Would you like to be entitled to euthanasia if you were to have incurable cancer?", whereas 240 $(\% 72,7)$ of others that are not healthcare professionals answered "no" to the same question, and thus a statistically significant difference $(\mathrm{p}<0.01)$ was found between the two groups in terms of their answers given to the said $7^{\text {th }}$ question. $62(\% 32,5)$ of the healthcare professionals responded to the $9^{\text {th }}$ question of this survey study, that is "If you were to be diagnosed with cancer, with whom and how would you first share that you have cancer?" by stating that they would not share it with anyone until the course of the disease became clear, whereas $151(\% 45,8)$ of others that are not healthcare professionals responded to the same question by stating that they would share it with a family member, and thus a statistically significant difference $(p<0.01)$ was found between the two groups in terms of their answers given to the said $9^{\text {th }}$ question. No statistically significant difference was found between the two groups in terms of answers given to other questions (Table 2).

\section{DISCUSSION}

We have conducted a survey study consisting of 11 questions taking into consideration the socio-demographic characteristics of the individuals in order to determine the difference between the perspectives of healthcare professionals and others that are not, towards cancer. We have found as a result of our study that the fear of contracting cancer was equally high between the healthcare professionals and others that are not healthcare professionals, despite the fact that participation rate of the others that are not healthcare professionals in cancer screening programs was found to be significantly low; which may be due to others having insufficient knowledge about these programs or not having access to health services. The use of vitamin supplements was found to be significantly higher among healthcare professionals compared to the others that are not healthcare professionals on the basis of the responses provided to the question, that is "Do you use vitamin supplements to prevent cancer?". Chemoprevention is the use of non-toxic organic or synthetic chemicals to prevent, delay, or reverse carcinogenesis (6). There is no clear consensus on chemoprevention. A natural and balanced diet is recommended for chemoprevention in general, whereas vitamin supplementation for this purpose is not recommended in the case of healthy individuals. Since carcinogenesis is multifactorial, it is not easy to determine whether the risk of cancer decreases with chemoprevention or not; as a matter of fact, different results have been obtained in the relevant studies conducted (7). Thus, it may be that healthcare professionals are taking dietary or vitamin supplements since their cancer awareness is greater. The responses provided to the question of "How would you like someone among your close ones to find about him/her having been diagnosed with cancer?" revealed that the number of people diagnosed with cancer was significantly higher in the healthcare professionals group. It is the right of any individual to be informed about his/her illness, and the decision whether to share his/her situation in question with others rests entirely with the patient, and his/her decision in this regard must be implemented by the doctor. Despite this, it is common in Turkey that the patient's close ones demand that the patient is not to be told about having been diagnosed with cancer. This demand arises from the idea that the patient will go into depression if he/she is to find about having been diagnosed with cancer, and that this will decrease his/her compliance to the treatment as a result, but it is the right of the patient to decide on his/her own treatment and he/she should not be of this right of his/ hers. Although most of the healthcare professionals responded to the question of "How would you like someone among your close ones to find about him/her having been diagnosed with cancer?" by stating that they would like their close one, who has been diagnosed with cancer, to be told directly about their diagnosis, giving rise to a statistically significant difference compared to the remaining healthcare professionals responded otherwise, the percentage of the remaining healthcare professionals (\%39.8), who have responded to the same question by stating that they would like their close one, who has been diagnosed with cancer, not to be told about their diagnosis and that another close one is to be told about it instead, was still quite high. The ratio of the healthcare professionals answered "yes" to the question of "Would you like to be entitled to euthanasia if you were to have incurable cancer?" was more than the ones answered "yes" to the same question among the group of others that are not healthcare professionals, and a statistically significant difference was found between the two groups in terms of their answers 


\begin{tabular}{|c|c|c|c|c|c|c|}
\hline \multirow[b]{3}{*}{ Variables } & \multicolumn{4}{|c|}{ Healthcare Professional } & \multirow[b]{3}{*}{$\mathbf{X}^{2}$} & \multirow[b]{3}{*}{$\mathbf{p}^{* *}$} \\
\hline & Yes & & No & & & \\
\hline & n & $\% *$ & n & $\% *$ & & \\
\hline \multicolumn{7}{|l|}{ 1. Do you have any fear that you can contract cancer? } \\
\hline Yes & 113 & 59,2 & 178 & 53,9 & \multirow{2}{*}{1,3} & \multirow{2}{*}{0,24} \\
\hline No & 78 & 40,8 & 152 & 46,1 & & \\
\hline \multicolumn{7}{|l|}{ 2. Have you participated in cancer screening programs? } \\
\hline Yes & 55 & 28,8 & 61 & 18,5 & \multirow{2}{*}{7,4} & \multirow{2}{*}{$<0,01$} \\
\hline No & 136 & 71,2 & 269 & 81,5 & & \\
\hline \multicolumn{7}{|l|}{ 3. Do you take vitamin supplements for cancer prevention? } \\
\hline Yes & 31 & 16,2 & 32 & 9,7 & \multirow{2}{*}{4,8} & \multirow{2}{*}{0,02} \\
\hline No & 160 & 83,8 & 298 & 90,3 & & \\
\hline \multicolumn{7}{|l|}{ 4. Do you have someone in your family or among your close ones diagnosed with cancer? } \\
\hline Yes & 110 & 57,6 & 141 & 42,7 & \multirow{2}{*}{10,7} & \multirow{2}{*}{$<\mathbf{0 , 0 1}$} \\
\hline No & 81 & 42,4 & 189 & 57,3 & & \\
\hline \multicolumn{7}{|l|}{ 5. Have you ever lost someone close to you due to cancer? } \\
\hline Yes & 99 & 51,8 & 147 & 44,5 & \multirow{2}{*}{2,5} & \multirow{2}{*}{0,10} \\
\hline No & 92 & 48,2 & 183 & 55,5 & & \\
\hline \multicolumn{7}{|l|}{$\begin{array}{l}\text { 6. How would you like someone among your close ones to find about him/her having been } \\
\text { diagnosed with cancer? }\end{array}$} \\
\hline a- I would like it to be told directly to him/her. & 115 & 60,2 & 141 & 42,7 & \multirow{3}{*}{14,7} & \multirow[b]{2}{*}{$<\mathbf{0 , 0 1}$} \\
\hline $\begin{array}{l}\text { b. I would like it to be told to someone that is close to him/her without being told to him/ } \\
\text { her. }\end{array}$ & 76 & 39,8 & 189 & 57,3 & & \\
\hline \multicolumn{6}{|l|}{ 7. Would you like to be entitled to euthanasia if you were to have incurable cancer? } & \\
\hline a. I wouldn't want euthanasia. & 114 & 59,7 & 240 & 72,7 & \multirow{3}{*}{11,7} & \multirow{3}{*}{$<\mathbf{0 , 0 1}$} \\
\hline $\begin{array}{l}\text { b. I wouldn't want euthanasia if I am young; I would want euthanasia however if I am old } \\
\text { and poor. }\end{array}$ & 48 & 25,1 & 46 & 13,9 & & \\
\hline c. I would want euthanasia. & 29 & 15,2 & 44 & 13,3 & & \\
\hline \multicolumn{7}{|l|}{ 8. Where would you like to spend the rest of your life if you had incurable cancer? } \\
\hline a. I would like to spend it in the hospital. & 25 & 13,1 & 30 & 9,1 & & \\
\hline b. I would like to spend it away from where I live. & 36 & 18,8 & 51 & 15,5 & 3,5 & 0,16 \\
\hline c. I would like to spend it at home with my family. & 130 & 68,1 & 249 & 75,5 & & \\
\hline $\begin{array}{l}\text { 9. If you were to be diagnosed with cancer, with whom and how would you first share that } \\
\text { you have cancer? }\end{array}$ & & & & & & \\
\hline a. I would not share it with anyone until the course of the disease became clear. & 62 & 32,5 & 79 & 23,9 & & \\
\hline b. I would share it with a close friend of mine. & 40 & 20,9 & 25 & 7,6 & 30,3 & $<0,01$ \\
\hline c. I would share it with another family member. & 57 & 29,8 & 151 & 45,8 & & \\
\hline d. I would have consulted my doctor. & 32 & 16,8 & 75 & 22,7 & & \\
\hline 10. Would you be willing to try herbal remedies if you had cancer? & & & & & & \\
\hline Yes & 107 & 56 & 187 & 56,7 & 01 & 080 \\
\hline No & 84 & 44 & 143 & 43,3 & 0,1 & 0,00 \\
\hline 11. Would you be willing to participate in the drug trial for your incurable cancer? & & & & & & \\
\hline Yes & 87 & 45,5 & 163 & 49,4 & 07 & 0.30 \\
\hline No & 104 & 54,5 & 167 & 50,6 & , i & \\
\hline
\end{tabular}

* Column Percent

** Chi-square test 
given to this question. In the study conducted on cancer patients treated in the palliative care unit, the rate of patients that accept euthanasia in the group receiving chemotherapy was found as $58.1 \%$, whereas the rate of patients that accept euthanasia in the group not receiving chemotherapy was found as $18.8 \%$. Apart from chemotherapy, age, belief in God, and living alone were among the other parameters, which were found to be significant in making euthanasia decisions, whereas parameters such as gender, educational status, being regularly informed after the treatment, pain and paroxysmal pain were not found to be significant in making euthanasia decisions (8). Euthanasia is essentially implemented as either active or passive euthanasia. Active euthanasia includes direct administration of the lethal substance to the patient, for whom there is no therapy available. On the other hand, passive euthanasia is an indirect process, in which the machines that keep the patient alive are shut down or the medications intended for temporary and partial treatment are discontinued, and no other treatment is implemented other than the treatments intended for pain relief (9). Euthanasia is legally practiced only in Belgium, the Netherlands, Luxembourg, Canada, and some states of the United States in the world, and it is not legal in our country. As an answer to the question of "Where would you like to spend the rest of your life if you had incurable cancer", both groups stated that they would want to have had spent it together with their families, and no significant difference was found between the groups in terms of the answers given to this question. Because cancer patients do not know the effectiveness of the treatment implemented and since they see cancer-related deaths in their surroundings, fear of death may develop. For this reason, they want to spend the rest of their lives during the treatment and the post-treatment period with their loved ones and especially with their families. The fact that similar responses were provided as an answer to this question in both groups regardless of their professions may be important evidence that the concept of family is of the same importance among the groups (10). Rate of the answer of "I would try herbal remedies for cancer treatment" and rate of the answer given to the question of "Would you be willing to participate in the drug trial for your incurable cancer?" was found to be similar in both groups. Despite all the developments in the medical field, the prevalence of cancer around the world, and the nontherapeutic treatment methods lead patients to seek and use non-conventional treatment methods (11). Cancer patients are increasingly using complementary therapies and medications to increase the effectiveness of the treatment, reduce the side effects associated with the treatment, and improve the quality of life (12). There are various types of complementary and alternative medicine applied in various parts of the world. The use of plants, which have an important role in complementary and alternative medicine applications, in cancer patients may cause concern especially due to the ingredients they contain and the fact that the properties of some of these plants have yet to be clarified. However, traditional medical practices followed in India and China are frequently used by cancer patients (13).

\section{CONCLUSION}

In conclusion, this study, which has been conducted with the aim of determination of the differences perspectives of healthcare professionals and others towards cancer, is the first study conducted in this subject in the literature, and it would be possible to have a more comprehensive idea about the perspectives of healthcare professionals and others towards cancer, by supporting this study by means of any further similar studies to be carried out or with different questions to be included in the questionnaire.

\section{Ethics Committee Approval: Yes \\ Conflict of Interest: None \\ Funding: None \\ Informed Consent: Yes}

\section{REFERENCES}

1. Meyer AC, Drefahl S, Ahlbom A, Lambe M, Modig K. Trends in life expectancy: did the gap between the healthy and the ill widen or close? BMC Med. 2020; 18(1): 41. https://doi.org/10.1186/s12916-020-01514-z

2. Forouzanfar MH, Afshin A, Alexander LT, Anderson HR, Bhutta ZA, Biryukov S, et al.; GBD 2015 Risk Factors Collaborators. Global, regional, and national comparative risk assessment of 79 behavioral, environmental and occupational, and metabolic risks or clusters of risks, 19902015: a systematic analysis for the Global Burden of Disease Study 2015. Lancet. 2016; 388(10053): 1659-724. https://doi.org/10.1016/S0140-6736(16)31679-8

3. Cho J, Choi EK, Shin DW, Cho B, Kim C, Koh DH et al. Association Between Cancer Stigma and Depression among Cancer Survivors: A Nationwide Survey in Korea. PsychoOncology. 2013; 22(10): 2372-8. https://doi.org/10.1002/pon.3302

4. Beek FEV, Wijnhoven LMA, Jansen F, Custers JAE, Aukema EJ, Coupé VMH, et al. Prevalence of adjustment disorder among cancer patients, and the reach, effectiveness, cost-utility and budget impact of tailored psychological treatment: study protocol of a randomized controlled trial. BMC Psychol. 2019; 7: 89. https://doi.org/10.1186/s40359-019-0368-y

5. Yoo GJ, Aviv C, Levine EG, Ewing C, Au A. Emotion work: disclosing cancer. Supportive Care in Cancer. 2010; 18(2): 205-15. https://doi.org/10.1007/s00520-009-0646-y

6. Miodrag N. Krstic Dragana D. Mijac Dusan D. Popovic Aleksandra Pavlovic Markovic Tomica Milosavljević. General Aspects of Primary Cancer Prevention. Dig Dis. 2019; 37: 406-415. https://doi.org/10.1159/000497191 
7. Fitzmaurice C, Allen C, Barber RM, Barregard L, Bhutta $\mathrm{ZA}$, Brenner H, et al.; Global Burden of Disease Cancer Collaboration. Global, regional, and national cancer incidence, mortality, years of life lost, years lived with disability, and disability-adjusted life years for 32 Cancer Groups, 1990 to 2015. A systematic analysis for the Global Burden of Disease Study. JAMA Oncol. 2017; 3(4): 524548.

https://doi.org/10.1001/jamaoncol.2016.5688

8. Nonneville AD, Chabal T, Marin A, Piana JML, Fichaux M, Tuzzolino V, et al. Determinants of favorable or unfavorable opinion about euthanasia in a sample of French cancer patients receiving palliative care. BMC Palliative Care. 2018; 17: 104-110.

https://doi.org/10.1186/s12904-018-0357-6

9. Toni C Saad. Euthanasia in Belgium: Legal, Historical and Political Review. Issues Law Med. 2017; 32(2): 183-204.

10. Bužgová R, Janíková E. Czech Adaption of the Collett-
Lester Fear of Death Scale in a Sample of Nursing Students. 2019; 80(1): 20-34.

https://doi.org/10.1177/0030222817725183

11. Arslan D, Tural D, Akar E. Herbal Administration and Interaction of Cancer Treatment. Journal of Palliative Medicine. 2013; 16(11): 1466-1476.

https://doi.org/10.1089/jpm.2013.0126

12. Smith CA, Hunter J, Delaney GP, Ussher JM, Templeman K, Grant S, Oyston E. Integrative oncology and complementary medicine cancer services in Australia: findings from a national cross-sectional survey. BMC Complement Altern Med. 2018; 18: 289.

https://doi.org/10.1186/s12906-018-2357-8

13. Leone S, Recinella L, Chiavaroli A, Orlando G, Ferrante C, Leporini L, et al. Phytotherapic use of the Crocus sativus L. (Saffron) and its potential applications: A brief overview. Phytother Res. 2018; 32(12): 2364-2375.

https://doi.org/10.1002/ptr.6181 